\title{
The Effect Of Competence And Facilities On Teacher's Performance At Haji Masri Darul Ilmi Murni Islamic Educational Foundation, Namorambe District, Deli Serdang Regency
}

\author{
Ega Siddik*1, Abd Rasyid Syamsuri ${ }^{2}$, Julianto Hutasuhut ${ }^{3}$, Mutawaqil Bilah Tumanggor ${ }^{4}$ \\ ${ }^{1}$ Student of Management Study Program, Faculty of Economics, Universitas Muslim \\ Nusantara Al Washliyah \\ ${ }^{2,3,4}$ Lecturer of Manajement Study Program, Faculty of Economics, Universitas Muslim \\ Nusantara Al Washliyah \\ Corresponding author: \\ *Email: egasiddik10@gmail.com
}

\begin{abstract}
:
This study aims to analyze the effect of competence and facilities have a positive and significant effect on teacher's performance at Haji Masri Darul Ilmi Murni Islamic Educational Foundation, Namorambe District, Deli Serdang Regency. The method used in this study is a quantitative method with several tests, that are the classical assumption test and multiple linear regression. Based on the results of the study, it can be seen that competence $\left(X_{1}\right)$ has a t-count value of 3.263 and a t-table of 1.663 when compared to t-count, the results are $3.263>1.663$, so it can be concluded that competence has a positive and significant effect on teacher performance $(Y)$. The facility $\left(X_{2}\right)$ has a t-count of 5.595 when compared to the $t$ table, the result is $5.595>1.663$, so it can be concluded that the facilities have a positive and significant effect on teacher's performance (Y). Simultaneously, competence and facilities have a positive and significant influence on teacher's performance. This means that the hypothesis in this study is accepted, proved by the calculated $F$ value $>F$ table $(75.790>3.11)$. The results of the coefficient of determination indicate that competence and facilities have an influence on teacher's performance by $65.2 \%$, while the remaining $34.8 \%$ is influenced by other variables which are not examined in this study.
\end{abstract}

Keywords: Competence, Facilities, Teacher's Performance.

\section{INTRODUCTION}

The success of an organization, both large and small success, are not solely determined by the available natural resources, but is greatly determined by the quality of Human Resources (Hr) who play roles in planning, implementing, and controlling the organization concerned. The continuity of development that is being conducted now in our country, however, can only be maintained if the quality of existing human resources gets serious attention from both the government and the private sector. Haji Masri Darul Ilmi Murni Islamic Educational Foundation is a school located in Namorambe District, Deli Serdang Regency. This school has dozens of educators (teachers) who are willing to nurture the students and school. The phenomenon of education at Haji Masri Darul Ilmi Murni Islamic Educational Foundation is that there are still teachers who do not have the competence to become educators/teachers. There are still teachers who do not have a Unique Educator Number and Education Personnel (NUPTK) and also there are still teachers who have not passed certification to become a teacher and also there are still teachers who do not meet the qualifications of a teacher with the level of education possessed by teachers at Haji Masri Darul Ilmi Murni Islamic Educational Foundation. It can be seen in table 1. that there are many teachers who do not have a Unique Educator Number and Education Personnel (NUPTK), and there are also teachers who have not passed certification and also teachers who do not meet the level of education and also their field of work (teacher). It can be explained in table 1. below:

Table 1. Teacher's Education and Certification

\begin{tabular}{|c|c|c|c|c|c|c|c|}
\hline \multirow[t]{2}{*}{ No } & \multirow[t]{2}{*}{$\begin{array}{c}\text { Teacher } \\
\text { Unit }\end{array}$} & \multicolumn{6}{|c|}{ Teacher's Competence } \\
\hline & & $\begin{array}{c}\text { Have } \\
\text { NUPTK }\end{array}$ & $\begin{array}{c}\text { Don't } \\
\text { have } \\
\text { NUPTK }\end{array}$ & $\begin{array}{l}\text { Passed the } \\
\text { Certification }\end{array}$ & $\begin{array}{l}\text { Haven't } \\
\text { passed the } \\
\text { Certificati- } \\
\text { on }\end{array}$ & $\begin{array}{c}\text { Compatibility } \\
\text { of Teacher } \\
\text { Qualifications } \\
\text { with Education }\end{array}$ & $\begin{array}{c}\text { Incompatibility } \\
\text { of Teacher } \\
\text { Qualifications } \\
\text { with Education }\end{array}$ \\
\hline
\end{tabular}




\begin{tabular}{|c|c|c|c|c|c|c|c|}
\hline 1 & $\begin{array}{c}\text { Kindergarten } \\
\text { teacher }\end{array}$ & $\begin{array}{c}4 \\
\text { Teachers }\end{array}$ & $\begin{array}{c}3 \\
\text { Teachers }\end{array}$ & $\begin{array}{c}2 \\
\text { Teachers }\end{array}$ & $\begin{array}{c}5 \\
\text { Teachers } \\
\end{array}$ & $\begin{array}{c}3 \\
\text { Teachers }\end{array}$ & $\begin{array}{c}4 \\
\text { Teachers }\end{array}$ \\
\hline 2 & $\begin{array}{l}\text { Elementary } \\
\text { teacher }\end{array}$ & $\begin{array}{c}24 \\
\text { Teachers }\end{array}$ & $\begin{array}{c}21 \\
\text { Teachers }\end{array}$ & $\begin{array}{c}3 \\
\text { Teachers }\end{array}$ & $\begin{array}{c}42 \\
\text { Teachers }\end{array}$ & $\begin{array}{c}43 \\
\text { Teachers }\end{array}$ & $\begin{array}{c}2 \\
\text { Teachers }\end{array}$ \\
\hline 3 & $\begin{array}{c}\text { Junior High } \\
\text { School } \\
\text { Teacher } \\
\end{array}$ & $\begin{array}{c}3 \\
\text { Teachers }\end{array}$ & $\begin{array}{c}14 \\
\text { Teachers }\end{array}$ & $\begin{array}{c}3 \\
\text { Teachers }\end{array}$ & $\begin{array}{c}14 \\
\text { Teachers }\end{array}$ & $\begin{array}{c}15 \\
\text { Teachers }\end{array}$ & $\begin{array}{c}2 \\
\text { Teachers }\end{array}$ \\
\hline 4 & $\begin{array}{c}\text { Senior High } \\
\text { School } \\
\text { Teacher }\end{array}$ & 7 Teachers & 8 Teachers & $\begin{array}{c}5 \\
\text { Teachers }\end{array}$ & $\begin{array}{c}10 \\
\text { Teachers }\end{array}$ & $\begin{array}{c}13 \\
\text { Teachers }\end{array}$ & $\begin{array}{c}2 \\
\text { Teachers }\end{array}$ \\
\hline & Total & $\begin{array}{c}38 \\
\text { Teachers }\end{array}$ & $\begin{array}{c}46 \\
\text { Teachers }\end{array}$ & $\begin{array}{c}13 \\
\text { Teachers }\end{array}$ & $\begin{array}{c}71 \\
\text { Teachers }\end{array}$ & $\begin{array}{c}74 \\
\text { Teachers }\end{array}$ & $\begin{array}{c}10 \\
\text { Teachers }\end{array}$ \\
\hline
\end{tabular}

Source: Haji Masri Darul Ilmi Murni Islamic Educational Foundation, 2021.

Table 1 can show that the phenomenon of teacher competence at the Haji Masri Darul Ilmi Murni Islamic Educational Foundation, there are still many teachers who do not have a Unique Number of Educators and Education Personnel (NUPTK), have not passed certification and also are not in accordance with educational qualifications. The existence of this phenomenon illustrates that the competence for teacher education at the Haji Masri Darul Ilmi Murni Islamic Educational Foundation is not suitable with the professionalism of a teacher. In addition, there are still some facilities at the Haji Masri Darul Ilmi Murni Islamic Education Foundation, Namorambe District, Deli Serdang Regency, which are not available to meet the school standards. This can be seen in table 2, which indicates that there are still many facilities and infrastructures that are not available at the Haji Masri Darul Ilmi Murni Islamic Education foundation. School facilities are identified with educational facilities and infrastructure that have been fulfilled, so that the students learning process can run effectively. The following are the facilities and infrastructure available at the Haji Masri Darul Ilmi Murni Islamic Education Foundation, Namorambe District, Deli Serdang Regency.

Table 2. Facilities and Infrastructures of Islamic Educational Foundation Haji Masri Darul Ilmi Murni.

\begin{tabular}{clc}
\hline No & \multicolumn{1}{c}{ Facilities } & Information \\
\hline 1 & Principal's Office & Available \\
\hline 2 & Teacher's Office & Available \\
\hline 3 & Mosque & Available \\
\hline 4 & Classroom (Equipped with AC, Infocus) & Available \\
\hline 5 & School Health Unit Room & Available \\
\hline 6 & Futsal field (Indoor) & Available \\
\hline 7 & Soccer Field & Available \\
\hline 8 & Basketball Court & Available \\
\hline 9 & Volleyball Field & Available \\
\hline 10 & Canteen & Available \\
\hline 11 & Computer Laboratory & Available \\
\hline 12 & School Sarpras Warehouse & Available \\
\hline 13 & CCTV in Every Building & Not Available \\
\hline 14 & Floor-level Toilet & Available \\
\hline 15 & Geography Laboratory & Not Available \\
\hline 16 & Teacher's Parking & Not Available \\
\hline 17 & Shuttle Bus & Not Available \\
\hline 18 & Multipurpose Building & Available \\
\hline 19 & Special Meeting Room & Not Available \\
\hline 20 & Chemistry Laboratory & Not Available \\
\hline 21 & Counseling Room & Available \\
\hline 22 & Library & Available \\
\hline 23 & Wifi Connection in Every Building & Not Available \\
\hline 24 & Documentation Tool & Not Available \\
\hline 25 & Language Laboratory & Not Available \\
\hline 26 & Music Extracurricular Studio & Not Available \\
\hline & &
\end{tabular}




27 Recording Studio $\quad$ Not Available

Source: Haji Masri Darul Ilmi Murni Islamic Educational Foundation, 2021.

The facilities and infrastructure owned by Haji Masri Darul Ilmi Murni Islamic Educational Foundation, Namorambe District, Deli Serdang Regency are not adequate. This can be seen from table 2 . There are still many facilities and infrastructures that are not yet available because the construction of these facilities has not been conducted. It can be seen in table 2 that the facilities that are not yet available are CCTV in every building, Geography Laboratory, Teacher's Parking, Shuttle Bus, Special Meeting Room, Chemistry Laboratory, Wifi connection in every building, Documentation Equipment, Language Laboratory, Music Extracurricular Studio and Recording Studio.

The research phenomenon on teacher's performance can be seen from the quality and quantity of teacher's performance which is still not effective and efficient and some have even not been realized. This is because the impact of the Covid-19 pandemic has caused the learning activities at Haji Masri Darul Ilmi Murni Islamic Educational Foundation, Namorambe District, Deli Serdang Regency become less effective. The impact of Covid-19 shows that teachers at Haji Masri Darul Ilmi Murni Islamic Educational Foundation are not optimal in conducting learning activities. The use of websites to support learning activities has not been implemented properly. The available website is only used for New Student Registration (PSB) via online, but the website itself is not used to conduct learning activities so that it gave an impact on the ineffectiveness of learning activities during the Covid-19 pandemic.

Observations made by the author regarding teacher performance based on quality and quantity can be seen in Tables 3 and 4 below:

Table 3. Teacher's Performance Quality

\begin{tabular}{cll}
\hline No & \multicolumn{1}{c}{ Teacher's Performance Quality } & \multicolumn{1}{c}{ Information } \\
\hline 1 & Designing lesson plans & Effective \\
\hline 2 & Conducting learning activities & Effective \\
\hline 3 & Assessing student learning outcomes & Not Effective \\
\hline
\end{tabular}

Source: Haji Masri Darul Ilmi Murni Islamic Educational Foundation, 2021

Tabel 4. Teacher's Performance Quantity

\begin{tabular}{c|ccc}
\hline No & \multicolumn{1}{c}{$\begin{array}{c}\text { Teacher's Performance } \\
\text { Quantity }\end{array}$} & Time & Information \\
\hline 1 & Learning implementation & 1 Year (2 Semesters) & Realized \\
\hline 2 & Evaluation implementation & 1 Year (2 Semesters) & Not Realized \\
\hline 3 & Evaluation analysis & 1 Year (2 Semesters) & Not Realized \\
\hline
\end{tabular}

Source: Haji Masri Darul Ilmi Murni Islamic Educational Foundation, 2021

Tables 3 and 4 show that the quality of the performance of Haji Masri Darul Ilmi Murni Islamic Educational Foundation teachers regarding to the assessment of learning outcomes for students is not effective, because there is still impacts of the Covid-19 pandemic which has resulted in the teaching and learning system still not being face-to-face meeting (online). Therefore, the assessment of students learning outcomes is still not effective.

The quantity of teacher performance in terms of conducting evaluations and also evaluation analysis was also not realized, due to the impact of the Covid-19 pandemic which resulted in the teaching and learning activities were not conducted face-to-face (online). Based on the research phenomenon that has been described on the background of the problem, the authors conducted a research analysis entitled The Effect of Competence and Facilities on Teacher's Performance at Haji Masri Darul Ilmi Murni Islamic Education Foundation, Namorambe District, Deli Serdang Regency.

\section{METHOD}

The research method used in this study is quantitative descriptive associative, research that is a causal relationship between two or more variables. Data collection techniques are observation, interviews and questionnaires. The population in this study was obtained from all teachers at Haji Masri Darul Ilmi 
Murni Islamic Educational Foundation, Namorambe District, Deli Serdang Regency, with the total amount: 84 people. The sampling technique used is saturated sampling which is a sampling technique if all members of the population are used as samples, [1]. Since the number of teachers at the Haji Masri Darul Ilmi Murni Islamic Education Foundation, Namorambe District, Deli Serdang Regency, for the academic year of 2020/2021, there are only 84 active teachers, so all teachers were taken as objects of research. The explanation for the variables in this study can be described from the following expert opinions: [2] suggested that competence is the ability to carry out something that is obtained through education and training. Competence becomes an inseparable part of educational and teaching activities. The ability of teachers to create an educative communication atmosphere includes cognitive (intellectual) aspects such as materials mastery, affective attitudes, such as loving their profession and psychomotor (behavioral) aspects such as classroom management skills, assessing learning outcomes and others. Every organization wants to have quality human resources in the sense of meeting the competency requirements to be utilized in an effort in realizing the vision and achieving goals.

[3] stated that competence is a skill possessed by a teacher in the form of cognitive aspects, affective aspects and psychomotor aspects needed in conducting their duties as a teacher so that they can run their duties properly. The main purpose to be pursued in the teaching and learning process is learning outcomes. Recently, the teachers do not evaluate themselves about the expertise they own, the teacher only focuses on students' low learning outcomes because of the students small interest in learning. The low learning outcomes are caused by the lack of student persistence when studying in class. The competency indicators in this study were taken from the opinion [4] which stated that human resources will only be obtained from employees or organizational members who meet the following characteristics: a) Have full knowledge of the duties, responsibilities and authorities. b) Have the necessary knowledge related to the full implementation of their duties. c) Able to do the tasks that must be done because they have the necessary skills. d) Be productive, innovative/creative, willing to cooperate with others, trustworthy, and loyal.

According to [5], learning facilities are equipment that supports learning activities at school that functioned to facilitate the learning process and fulfill the needs of the learning process. School facilities are identical to educational facilities and infrastructure. Educational facilities are all devices, equipment, materials, and furniture that are directly used in the education process at schools and educational infrastructure are all basic equipment that indirectly supports the implementation of the educational process at schools, [6]. According to [7] the indicators of learning facilities consist of a) room or place to study, which is a requirement to be able to study as well as possible and the availability of special learning places. Each student should use a special learning place, comfortable or spacious enough to conduct learning activities, attractive wall colors, equipped with air ventilation and adequate lighting. b) Study furnitures, such as study equipment that help to achieve the learning process by providing a special study table, special study chair, study lamp, bookcase, cupboard/bookcase and shoe rack. c) Learning aids are complete stationery equipment, compasses, protractors, and calculators and laptops or computers. The more complete the tools, the better the learning process will be. d) Learning resources including textbooks, internet access, radio, magazines or newspapers, and television. The internet can be accessed with a mobile phone, laptop or computer connected to the internet. Indicators of learning facilities that are used as benchmarks in this study include: a) Study room, learning equipment. c) Laptop/mobile phone, and d) Internet connection.

[8] stated that "teacher performance is the ability of a teacher in conducting learning tasks at school and responsible for the students under his guidance by improving the achievement or learning outcomes of his/her students". The indicators used to measure teacher performance in this study consisted of: a) lesson plan preparation, b) implementation of the learning process, c) Guiding and training students, d) Guiding and training students, e) implementation of learning evaluations. Several descriptions have been stated regarding to the effect of competence and facilities on teacher performance at Haji Masri Darul Ilmi Murni Islamic Educational Foundation, Namorambe District, Deli Serdang Regency, it can be stated that the hypothesis of this study consists of: 1) There is an influence between Competence on teacher's performance at Haji Masri Darul Ilmi Murni Islamic Educational Foundation, Namorambe District, Deli Serdang Regency. 2) There is 
an influence between facilities on teacher performance at Haji Masri Darul Ilmi Murni Islamic Educational Foundation, Namorambe District, Deli Serdang Regency. 3) There is an influence between competence and facilities on teacher's performance at Haji Masri Darul Ilmi Murni Islamic Educational Foundation, Namorambe District, Deli Serdang Regency.

\section{RESULTS AND DISCUSSION}

The results of this study are used to answer all the hypotheses that have been stated previously. The results of the study were based on validity and reliability tests using 13 questions and a research sample of 30 teachers at the Al-Hasanah Ulumul Qur'an Islamic Education Foundation. The results of the validity and reliability tests in this study can be contained in Tables 5 and 6 below:

Table 5. Validity Test Results

\begin{tabular}{|c|c|c|c|}
\hline Item & $\begin{array}{c}\text { Corrected item- } \\
\text { Total Correlation } \\
\text { (r-count) }\end{array}$ & $\begin{array}{c}\text { Significant } \\
\text { Criteria }\end{array}$ & Information \\
\hline \multicolumn{4}{|c|}{ Competence $\left(\mathbf{X}_{1}\right)$} \\
\hline $\mathrm{X} 1.1$ & 0,875 & 0,5 & Valid \\
\hline $\mathrm{X} 1.2$ & 0,923 & 0,5 & Valid \\
\hline $\mathrm{X} 1.3$ & 0,522 & 0,5 & Valid \\
\hline $\mathrm{X} 1.4$ & 0,923 & 0,5 & Valid \\
\hline \multicolumn{4}{|c|}{ Facilities $\left(\mathrm{X}_{2}\right)$} \\
\hline $\mathrm{X} 2.1$ & 0,602 & 0,5 & Valid \\
\hline $\mathrm{X} 2.2$ & 0,942 & 0,5 & Valid \\
\hline $\mathrm{X} 2.3$ & 0,755 & 0,5 & Valid \\
\hline $\mathrm{X} 2.4$ & 0,878 & 0,5 & Valid \\
\hline \multicolumn{4}{|c|}{ Teachers' Competences (Y) } \\
\hline Y.1 & 0,865 & 0,5 & Valid \\
\hline Y.2 & 0,633 & 0,5 & Valid \\
\hline Y.3 & 0,850 & 0,5 & Valid \\
\hline Y.4 & 0,750 & 0,5 & Valid \\
\hline Y.5 & 0,819 & 0,5 & Valid \\
\hline
\end{tabular}

Source: Research Results, 2021

Table 5 shows that the distribution of questionnaires for Competence $\left(\mathrm{X}_{1}\right)$, Work Facilities $\left(\mathrm{X}_{2}\right)$, and Teacher Performance $(\mathrm{Y})$ has significant criteria $>0.05$, so it can be stated that all statement items are valid. Reliability test can be used to measure the instrument can be accounted for by looking at the consistency of answers from research respondents. Reliability testing with Alpha Cronbach's technique can seen in Table 6 below:

Table 6. Reliability Test Results

\begin{tabular}{lccc}
\hline \multicolumn{1}{c}{ Variable } & $\begin{array}{c}\text { Reliability Value } \\
\text { (Cronbach } \text { Alpha) }\end{array}$ & $\begin{array}{c}\text { Significant } \\
\text { Criteria }\end{array}$ & Information \\
\hline Competence (X1) & 0,826 & 0,6 & Reliable \\
\hline Facility (X2) & 0,805 & 0,6 & Reliable \\
\hline Teacher's Performance (Y) & 0,843 & 0,6 & Reliable \\
\hline
\end{tabular}

Source: Research Results, 2021

According to [9], said that the instrument that is said to be reliable if it has a reliability coefficient of 0.6 or more, if it is less than 0.6 then it is declared unreliable. Cronbach's Alpha coefficient of Competence $\left(\mathrm{X}_{1}\right)$ is 0.826 , Facilities $\left(\mathrm{X}_{2}\right)$ is 0.805 and Teacher's Performance $(\mathrm{Y})$ is 0.843 . When compared to the table of reliability level criteria, the reliability test results of the instrument variables studied in this study have a good level of reliability. The results of the next study using the classical assumption test consisting of: normality, multicollinearity and heteroscedasticity tests. The view of [10], normality test aims to test whether in the regression model, confounding variables or residuals have a normal distribution. The $t$ (partial) and $\mathrm{F}$ (simultaneous) tests assumed that the residual value follows a normal distribution. The way to detect whether the residuals are normally distributed or not is by graphical analysis using the Kolmogorov-Smirnov test. The results can be accepted well, if the significant value is greater than 0.05 at $(\mathrm{P}>0.05)$. Multicollinearity test aims to examine the regression model found a correlation between the independent variables 
(independent). Detection to determine the presence or absence of multicollinearity symptoms in the regression model of this study can be done by looking at the tolerance value. If the tolerance value is 0.10 or equal to the VIF value $\geq 10$, it indicates the presence of multicollinearity. If the tolerance value $\mathrm{e} \geq 0.10$ or equal to the VIF value 10, it shows that there is no multicollinearity. The next test used the heteroscedasticity test which aims to examine the regression model so that there is no similarity in variance from the residuals of one observation to another observation. Ways that can be done to examine heteroscedasticity, that are the graph plot test, and the glejser test. Research testing on the glejser test regressed the absolute value of the residue on the independent variable with the regression equation. The results of the study using the normality test using the p-plot graph can be displayed in Figure 1 below:

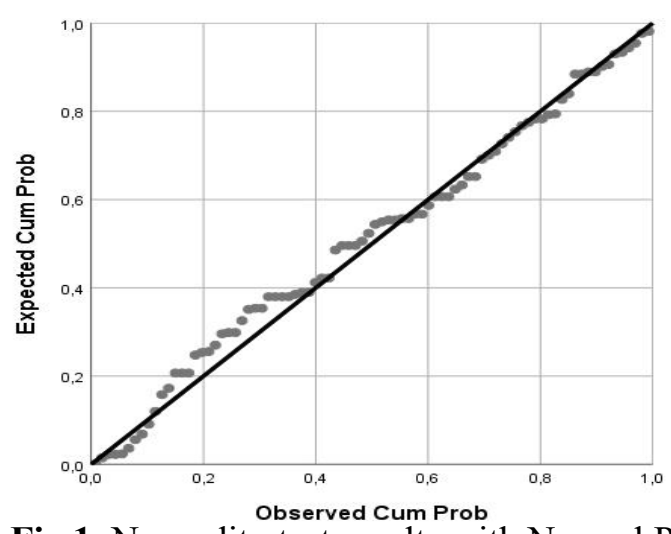

Fig 1. Normality test results with Normal P-P Plot graph

Source: Research Results, 2021.

Based on the normal P-P plot graph, it is known that the data spreads around the diagonal line and follows the direction of the diagonal line which indicates that the data has a normal distribution pattern. The results of the analysis using the Kolmogorov-Smirnov test can be seen in Table 7 below:

Table 7. Kolmogorov-Smirnov test results

\begin{tabular}{llr}
\hline N & & 84 \\
\hline Normal Parameters & Mean &, 0000000 \\
\cline { 2 - 3 } & Std. Deviation & 1,41768651 \\
\hline Most Extreme Differences & Absolute &, 076 \\
\cline { 2 - 3 } & Positive &, 037 \\
\cline { 2 - 3 } & Negative &,- 076 \\
\hline Test Statistic & &, 076 \\
\hline Asymp. Sig. (2-tailed) & &, $200^{\mathrm{c}, \mathrm{d}}$ \\
\hline
\end{tabular}

a. Test distribution is Normal.

b. Calculated from data.

c. Lilliefors Significance Correction.

d. This is a lower bound of the true significance.

Source: Research Results, 2021

Table 7 contains the results of the Kolmogorov-Smirnov test with the Asymp value. Sig. (2 -tailed) of 0,200 is greater than 0,05 so it can be stated that the tested data is normally distributed. The results of the heteroscedasticity test can be displayed through Figure 2 of the following scatter plot graph:

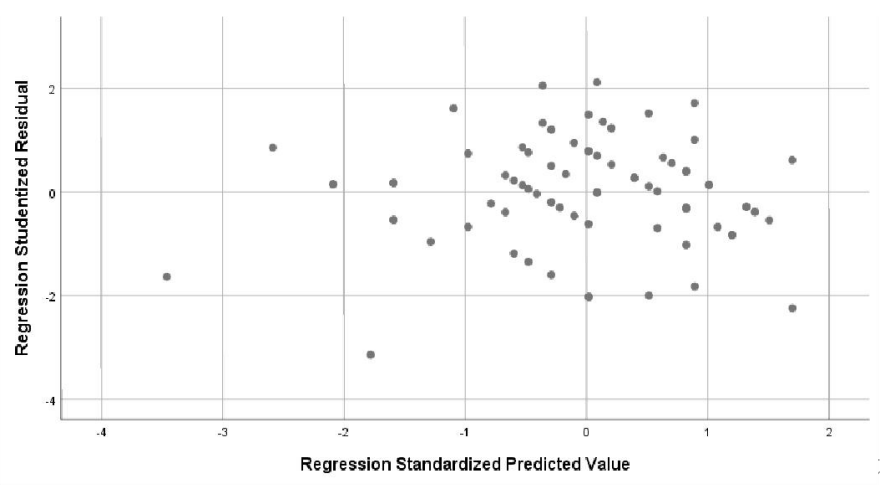

$\underline{\text { http://ijstm.inarah.co.id }}$ 
Source: Research results, 2021

Based on the scatterplot graph, it can be seen that there is no clear pattern and the points spread above and below the number 0 on the $\mathrm{Y}$ axis so it can be concluded that there is no heteroscedasticity. The results of the multicollinearity test that were tested using SPSS software can be seen in Table 8 below:

Table. 8 Multicollinearity Test Results

\begin{tabular}{l|lrr}
\hline \multicolumn{3}{c}{ Coefficients $^{\mathbf{a}}$} \\
\cline { 3 - 4 } \multicolumn{2}{c}{ Model } & \multicolumn{2}{c}{ Collinearity Statistics } \\
\hline \multirow{2}{*}{1} & (Constant) & \multicolumn{2}{c}{ Tolerance } \\
\cline { 2 - 4 } & Competence &, 455 & 2,199 \\
\cline { 2 - 4 } & Facilities &, 455 & 2,199 \\
\hline
\end{tabular}

a. Dependent Variable: Teacher Performance

Source: Research Results, 2021

Table 8 , regarding the results of the multicollinearity test, it can be explained that the tolerance value is 0.455 $>0.1$ and the VIF value is $2.199<10$. These results indicate that there is no multicollinearity in the regression model. The results of multiple linear regression analysis in this study can be shown in Table 9 below:

Table 9. Multiple Linear Regression Analysis

\begin{tabular}{|c|c|c|c|c|c|c|c|}
\hline \multicolumn{7}{|c|}{ Coefficients $^{a}$} & \multirow{6}{*}{$\begin{array}{l}\text { Dependent } \\
\text { Variable: } \\
\text { Teacher }\end{array}$} \\
\hline \multirow{2}{*}{\multicolumn{2}{|c|}{ Model }} & \multicolumn{2}{|c|}{$\begin{array}{l}\text { Unstandardized } \\
\text { Coefficients }\end{array}$} & \multirow{2}{*}{$\begin{array}{c}\begin{array}{c}\text { Standardized } \\
\text { Coefficients }\end{array} \\
\text { Beta }\end{array}$} & \multirow[t]{2}{*}{$\mathrm{t}$} & \multirow[t]{2}{*}{ Sig. } & \\
\hline & & $\mathrm{B}$ & Std.Error & & & & \\
\hline \multirow[t]{3}{*}{1} & (Constant) & 4,866 & 1,325 & & 3,673 &, 000 & \\
\hline & Competency & ,367 &, 112 & 317 & 3,263 &, 002 & \\
\hline & Facility & ,597 & , 107 &, 544 & 5,595 & .000 & \\
\hline
\end{tabular}

Performance

Source: Research Results, 2021

The results of the study indicate that the constant value (a) is 4.866 and the competency regression coefficient $\left(\mathrm{X}_{1}\right)$ is 0.367 which indicates that competence has a positive effect on teacher's performance, so that if competency is increased by 1 unit, teacher's performance will increase by 0.367 . The facility regression coefficient value $\left(\mathrm{X}_{2}\right)$ is 0.597 which indicates that the facility has a positive effect on teacher performance, so that if the facility is increased by 1 unit, the teacher's performance will increase by 0.597 . The results of the partial test $(\mathrm{t})$ in this study can be seen in table 10. below:

Table 10. Partial test results (t-test)

\begin{tabular}{|c|c|c|c|c|c|c|}
\hline \multicolumn{7}{|c|}{ Coefficients $^{\mathrm{a}}$} \\
\hline \multirow{2}{*}{\multicolumn{2}{|c|}{ Model }} & \multicolumn{2}{|c|}{$\begin{array}{l}\text { Unstandardized } \\
\text { Coefficients }\end{array}$} & \multirow{2}{*}{$\begin{array}{c}\begin{array}{c}\text { Standardized } \\
\text { Coefficients }\end{array} \\
\text { Beta } \\
\end{array}$} & \multirow[t]{2}{*}{$\mathrm{t}$} & \multirow[t]{2}{*}{ Sig. } \\
\hline & & B & Std.Error & & & \\
\hline \multirow[t]{3}{*}{1} & (Constant) & 4,866 & 1,325 & & 3,673 &, 000 \\
\hline & Competency & ,367 &, 112 & ,317 & 3,263 &, 002 \\
\hline & Facility & ,597 & , 107 &, 544 & 5,595 &, 000 \\
\hline
\end{tabular}

Dependent Variable: Teacher

Performance

Source: Research Results, 2021.

Table 10. shows that competence has a significant $0.002<0.05$, which means that competence has a significant effect on teacher performance at Haji Masri Darul Ilmi Murni Islamic Education Foundation, Namorambe District, Deli Serdang Regency. When viewed by comparing the value of $t$ table, it is known that the significant level of this study is $5 \%(0.05)$, with the number of df is 84 (nk-1 or $84-2-1$ ), based on these data it can be determined the size of the t table is 1.663, and it is known that Competence has a $t$ count of 3.263, when compared to the t table, the result is $3.263>1.663$, so it can be stated that competence has a significant effect on teacher's performance. The facility has a t-count of 5.510, when compared to the t-table, the result is $5.595>1.663$, so it can also be stated that the facility has a significant effect on teacher's performance. The results of the partial test $(\mathrm{F})$ in this study can be displayed in table 11 below: 
Table 11. F Test Results

ANOVA ${ }^{a}$

\begin{tabular}{|c|c|c|c|c|c|c|}
\hline \multicolumn{2}{|c|}{ Model } & Sum of Squares & $\mathrm{df}$ & Mean Square & $\mathrm{F}$ & Sig. \\
\hline 1 & Regression & 312,172 & 2 & 156,086 & 75,790 &, $000^{\mathrm{b}}$ \\
\hline & Residual & 166,816 & 81 & 2,059 & & \\
\hline & Total & 478,988 & 83 & & & \\
\hline
\end{tabular}

a. Dependent Variable: Teacher Performance

b. Predictors: (Constant), Facilities, Competence

Source: Research Results, 2021

Table 11, shows that the results of the $\mathrm{F}$ test have a calculated $\mathrm{F}$ value of 75.790 while the $\mathrm{F}$ table value is 3.11 then the calculated $\mathrm{F}$ value $>\mathrm{F}$ table $(75.790>3.11)$ which means that Competence and Facilities simultaneously have a positive and significant effect on teacher's performance. The results of the coefficient of determination $\left(\mathrm{R}^{2}\right)$ in this study can be seen through the following table 12 below:

Table. 12. Coefficient of determination $\left(\mathrm{R}^{2}\right)$

\begin{tabular}{|c|c|c|c|c|}
\hline \multirow[b]{2}{*}{ Model } & \multicolumn{3}{|c|}{ Model Summaryb } & \multirow[b]{2}{*}{$\begin{array}{l}\text { Std. Error of the } \\
\text { Estimate }\end{array}$} \\
\hline & $\mathrm{R}$ & R Square & $\begin{array}{c}\text { Adjusted R } \\
\text { Square }\end{array}$ & \\
\hline 1 & $807^{\mathrm{a}}$ & ,652 & ,643 & 1,435 \\
\hline
\end{tabular}

Based on the results of the regression calculation of the coefficient of determination of the summary model in table 12, it can be seen that the coefficient of determination $\left(\mathrm{R}^{2}\right)$ obtained in this study is 0.652 . This means that $65.2 \%$ of teacher's performance can be influenced by competence and facilities while the remaining $34.8 \%$ can be influenced by other independent variables which are not included in this study.

\section{CONCLUSION}

Based on the analysis and discussion results of the influence of competence and facilities on teacher performance at Haji Masri Darul Ilmi Murni Islamic Educational Foundation, Namorambe District, Deli Serdang Regency, the conclusions of this study are: 1) Competence has a significant effect on teacher's performance at Haji Masri Darul Ilmi Murni Islamic Educational Foundation, Namorambe District, Deli Serdang Regency. 2) Facilities have a significant effect on teacher's performance at Haji Masri Darul Ilmi Murni Islamic Educational Foundation, Namorambe District, Deli Serdang Regency. 3) Competence and facilities have a significant effect on teacher performance at Haji Masri Darul Ilmi Murni Islamic Educational Foundation, Namorambe District, Deli Serdang Regency.

\section{REFERENCES}

[1] Sugiyono. Metode Penelitian Pendidikan Pendekatan Kuantitatif, Kualitatif, dan R \& D. Bandung: Alfabeta, 2017.

[2] Mulyasa, E. Standar Kompetensi dan Sertifikasi Guru, Bandung, Remaja Rosda Karya: Bandung, 2013

[3] Marheni, Sujana, \& Putra, S. Penerapan model pembelajaran kooperatif tipe STAD untuk meningkatkan keaktifan dan hasil belajar IPS kelas V SD no. 8 Padangsambian Denpasar. MIMBAR PGSD Ejournal Undiksha. https://doi.org/http://dx.doi.org/10.23887/jjpgsd.v1i1.1438, 2013.

[4] Sutrisno, E. Manajemen Sumber Daya Manusia, Jakarta, Kencana, 2017.

[5] Darmadi, Pengembangan Model dan Metode Pembelajaran dalam Dinamika Belajar Siswa. Yogyakarta, Deepublish, 2017.

[6] Barnawi, M. Arifin, Manajemen Sarana dan Prasarana sekolah.Yogyakarta: Ar-Ruzz Media, 2012

[7] Slameto. Belajar \& Faktor-faktor yang mempengaruhinya, Jakarta, Rineka Cipta, 2013

[8] Supardi. Kinerja Guru. Jakarta: Rajawali Press, 2016

[9] Rusdiana A., Irfan M, Sistem Informasi Manajemen, Bandung: Pustaka Setia, 2014.

[10] Ghozali, Imam. Aplikasi Analisis Multivariete dengan Program SPSS. Edisi ke-8. Semarang: Badan Penerbit Universitas Diponegoro, 2016 